\title{
Expression and presence of osteopontin and integrins in the bovine oviduct during the oestrous cycle
}

\author{
C. Gabler, D. A. Chapman and G. J. Killian* \\ John O. Almquist Research Center, Department of Dairy and Animal Science, Pennsylvania State \\ University, University Park, PA 16802, USA
}

\begin{abstract}
Osteopontin and integrin $\boldsymbol{\alpha}_{\mathrm{v}} \beta_{3}$ are known to mediate cellcell attachment and cell migration. Western blot analysis was used to demonstrate the presence of osteopontin in oviductal fluid collected from ampullar and isthmic regions. Three different osteopontin isoforms of $55 \mathrm{kDa}$, $48 \mathrm{kDa}$ and $25 \mathrm{kDa}$ were detected in the oviductal fluid. Each isoform was observed during the luteal and nonluteal phases and in both ampullar and isthmic fluids. The $25 \mathrm{kDa}$ osteopontin was the most prevalent isoform in oviductal fluid except in isthmic fluid during the nonluteal phase of the oestrous cycle. RT-PCR was performed with RNA from oviductal cells collected from cows in the post-ovulatory, early to mid-luteal, late luteal or preovulatory stages of the oestrous cycle to reveal the oviduct
\end{abstract}

as a site of osteopontin and integrin synthesis. Only one osteopontin mRNA transcript was detected, and amounts did not vary throughout the oestrous cycle. In contrast, the relative expression of the integrin subtypes $\alpha_{v}$ and $\beta_{1}$ during the late luteal phase was lower compared with the other oestrous cycle phases. Integrin $\beta_{3}$ mRNA content increased significantly from the lowest level during the late luteal phase to the highest level before ovulation. In conclusion, differential presence of osteopontin isoforms and integrins in the bovine oviduct throughout the oestrous cycle indicate that osteopontin-integrin interactions have functional roles in normal oviduct physiology which may potentially influence interactions between the gametes, the embryo, and the epithelium.

\section{Introduction}

Osteopontin, also known as the early T-cell activation-1 (Eta-1) cytokine, is a negatively charged, glycosylated phosphoprotein with a polypeptide backbone approximating $31 \mathrm{kDa}$ (Kerr et al., 1991). Osteopontin was originally identified in the mineralized matrix of bovine bone (Franzen and Heinegard, 1985), but has subsequently been reported in a variety of organs, including female reproductive tissues such as the human ovary (Brown et al., 1992), the human and ovine endometrium (Nomura et al., 1988; Brown et al., 1992; Johnson et al., 1999a) and the human oviduct (Brown et al., 1992). Its presence has been also shown in several organs of the male reproductive tract including the bovine seminal vesicle and ampulla (Cancel et al., 1999), the epithelium of the human rete testis and prostate gland (Brown et al., 1992), and the rat testis and epididymis (Siiteri et al., 1995). In situ hybridization revealed that bovine spermatozoa located within the epididymis and ampulla contained osteopontin mRNA (Rodriguez et al., 2000). The relative amount of osteopontin in bovine seminal plasma is

*Correspondence

Email: gkillian@psu.edu correlated positively with the fertility of bulls (Cancel et al., 1997).

Multiple forms of osteopontin have been described, including differentially glycosylated, phosphorylated and sulphated isoforms, as well as naturally occurring proteolytic fragments (Denhardt and Guo, 1993). Analyses of the deduced bovine osteopontin amino acid sequence have revealed a hydrophobic secretory signal peptide sequence, one potential site for Asn-linked glycosylation, a stretch of consecutive Asp residues and the cell attachment argine-glycine-aspartic acid (RGD) peptide (Kerr et al., 1991). Bovine osteopontin has 22 fewer amino acids than that of other species. An interesting feature of this missing amino acid segment is that it is believed to be a potential $\mathrm{Ca}_{2}{ }^{+}$-binding site (Prince, 1989). In addition, osteopontin has a thrombin cleavage site, producing two fragments which potentially increase its biological activity (Denhardt and Guo, 1993; Senger et al., 1994). Identification of the RGD cell-binding domain in osteopontin provided the first indication that this protein may play a role in cell adhesion (Oldberg et al., 1986). It has been shown that osteoclasts adhere to the RGD-containing proteins, osteopontin and fibronectin (Helfrich et al., 1992), but this attachment by the cells was abolished in the presence of synthetic peptides containing the RGD sequence. Osteopontin 
binds primarily to an $\alpha_{v} \beta_{3}$ integrin heterodimer on tissues via its RGD sequence to promote cell-cell attachment, cell spreading and extracellular matrix communication (Miyauchi et al., 1991; Ross et al., 1993). Osteopontin also binds to the integrin heterodimers $\alpha_{v} \beta_{1}, \alpha_{v} \beta_{5}$ (Hu et al., 1995) and $\alpha_{9} \beta_{1}$ (Smith et al., 1996).

Integrins are non-convalently bound heterodimers with a cytoplasmic and an extracellular domain composed of a unique subfamily of specific $\beta$ chains and distinct $\alpha$ chains (Hynes, 1992). There are at least eight known $\beta$ subunits (90-110 kDa) and 14 known $\alpha$ subunits (120-180 kDa).

Several integrins were detected in the endometrium of humans and sheep (Lessey et al., 1992, 1994; Johnson et al., 1999b). In the human endometrium the $\alpha_{v} \beta_{3}$ integrin appeared abruptly on post-ovulatory days 5-6. Maximal osteopontin expression (mRNA and protein) was also observed during the mid- to late secretory phase in human endometrium (Apparao et al., 2001; von Wolff et al., 2001). The localization of osteopontin and the integrin $\alpha_{v} \beta_{3}$ at the apical surface of the epithelial cells indicates that they may participate in adhesion of the trophoblast to the endometrium at the onset of the implantation.

Furthermore, integrin $\beta 1$ was detected on ejaculated spermatozoa by flow cytometric analysis (Glander and Schaller, 1993) and on spermatogenic cells in human testis (Schaller et al., 1993). The presence of integrins on spermatozoa and the integrin ligand-binding domain on oocytes (Blobel et al., 1992) may indicate an involvement of these molecules in fertilization.

The appearance of osteopontin and several integrins in tissues of the male reproductive tract on spermatozoa and in the seminal fluid indicates that these molecules may influence reproduction. The presence and possible function of osteopontin and integrins and their receptors have been investigated in the uterus and endometrium of several species. However, little is known about their role in the oviduct at the site of fertilization.

The aims of this study were to examine oviductal fluid for the presence of osteopontin and to evaluate oviductal epithelial cells for mRNA expression of osteopontin and integrin $\alpha_{v}$, integrin $\beta_{1}$ and integrin $\beta_{3}$ subtypes to provide supportive evidence that osteopontin-integrin interactions are important for oviduct function or for fertilization and early embryo development.

\section{Material and Methods}

\section{Collection of oviductal fluid and cells}

Oviductal fluid was collected daily from indwelling ampullary and isthmic cannulae in 13 Holstein cows (Bos taurus) as described in detail by Kavanaugh et al. (1992). The stage of the oestrous cycle was determined by a progesterone radioimmunoassay using serum samples taken each day at the time of collection of oviductal fluid
(Killian et al., 1989). Samples with serum progesterone concentrations above $1.5 \mathrm{ng} \mathrm{m}^{-1}$ were considered to be luteal, whereas those with concentrations equal to or below $1.5 \mathrm{ng} \mathrm{ml}^{-1}$ were considered to be non-luteal. Visible signs of oestrus were also noted. Daily oviductal fluid samples previously stored in liquid nitrogen were thawed and combined from at least 7 cows into single pools for each oviductal region collected during the nonluteal or luteal phase. Pools were filtered $(0.45 \mu \mathrm{m})$ and stored at $-70^{\circ} \mathrm{C}$ until used.

Oviducts from Holstein cows were collected at an abattoir within 20 min of slaughter for RNA analysis. The oviducts were classified into one of four groups: post-ovulatory stage (days 1-5); early to mid-luteal stage (days 6-12); late luteal stage (days 13-18); and preovulatory stage (days 19-21). The stage of the oestrous cycle was defined by careful post mortem examination of the ovaries (follicles and corpora lutea) as well as of the uterus as described by Ireland et al. (1980). Whole oviducts were filled with $1 \mathrm{ml}$ PBS and the oviductal contents were squeezed in a $1.5 \mathrm{ml}$ microfuge tube. After centrifugation at $570 \mathrm{~g}$ for $3 \mathrm{~min}$ at $4^{\circ} \mathrm{C}$, the supernatant was removed and cell pellets of both oviducts of one cow were combined and stored at $-70^{\circ} \mathrm{C}$ until examined.

The verification of the type of cell ( $>60 \%$ epithelial cells) and oviductal cell viability (>99\%) was carried out as described by Gabler et al. (1997).

\section{SDS-PAGE and western blot analysis}

Protein concentrations of the different oviductal fluid pools were determined by the method of Bradford (1976) using BSA as the standard. Oviductal fluid protein samples $(100 \mu \mathrm{g})$ of each pool were separated by one-dimensional gradient SDS-PAGE under denaturing conditions. The separating gels were cast with a $10.0-17.5 \%(\mathrm{w} / \mathrm{v})$ acrylamide linear gradient. After electrophoresis, the proteins were immediately transferred to a nitrocellulose membrane $(0.45 \mu \mathrm{m}$; Schleicher \& Schuell, Keene, NH) using a semi-dry transfer protocol (Kyhse-Andersen, 1984) and a Milliblot semi-dry electroblotter (Millipore Corp., Bedford, MA). Nitrocellulose sheets were stained with Ponceau S $(0.5 \%$ $(\mathrm{w} / \mathrm{v})$ Ponceau S, $1 \%(\mathrm{v} / \mathrm{v})$ acetic acid in water) to assess the quality of the transfer and thereafter destained with water. Western blot analysis was performed as described by Cancel et al. (1997). The primary rabbit antibody, raised against bovine milk osteopontin, was diluted $1: 2000$ in PBS containing $0.1 \%(\mathrm{v} / \mathrm{v})$ Tween 20 and $5 \%(\mathrm{v} / \mathrm{v})$ normal goat serum. The specific osteopontinantibody binding was visualized using the ECL detection system (Amersham, Arlington Heights, IL) according to the manufacturer's instructions. The resulting developed films were scanned with an imaging densitometer (model GS-70, Bio-Rad Laboratories, Hercules, CA). 


\section{$R N A$ extraction and $R T-P C R$}

Total RNA was isolated from flushed oviductal cells by the single-step method of Chomczynski and Sacchi (1987) with TRIzol ${ }^{\circledR}$ Reagent (Life Technologies, Rockville, MD). The yield of total oviductal RNA was quantified with a UV spectrophotometer at a wavelength of $260 \mathrm{~nm}$. The quantity and integrity of the oviductal RNA was verified by checking the $28 \mathrm{~S}$ and $18 \mathrm{~S}$ ribosomal RNA bands after electrophoresis on a formaldehydecontaining $1 \%(\mathrm{w} / \mathrm{v})$ agarose gel.

Genomic DNA was removed by DNA digestion (Huang et al., 1996) in a first step of the reverse transcription. Briefly, the DNase I treatment was carried out in $20 \mu \mathrm{l}$ and contained $4 \mu \mathrm{g}$ total oviductal RNA, $4 \mathrm{U}$ DNase I (Ambion, Austin, TX), $50 \mathrm{mmol}$ Tris- $\mathrm{HCl}$

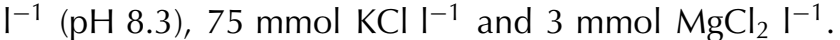
This reaction mixture was incubated at $37^{\circ} \mathrm{C}$ for $30 \mathrm{~min}$ and heated for $5 \mathrm{~min}$ at $75^{\circ} \mathrm{C}$ to inactivate the DNase. The samples were then placed immediately on ice. To each sample $140 \cup$ Superscript II reverse transcriptase (Life Technologies), $2.5 \mu \mathrm{mol}$ random hexamers $\mathrm{I}^{-1}$ (Amersham Biosciences, Piscataway, NJ), $0.60 \mathrm{mmol}$ dNTPs $\mathrm{I}^{-1}$ (Amersham Biosciences) and $10 \mathrm{mmol}$ dithiothreitol $\mathrm{I}^{-1}$ was added for a final volume of $60 \mu \mathrm{l}$. The reverse transcription was performed at $45^{\circ} \mathrm{C}$ for $30 \mathrm{~min}$ followed by $90^{\circ} \mathrm{C}$ for $2 \mathrm{~min}$.

The following commercially synthesized primers (Life Technologies) were used to amplify specific bovine transcripts. Osteopontin (387 bp, corresponding to bases 332-718 of the bovine sequence, EMBL accession no. M66236): forward 5' ACG ATG ATG ATA ACA GCC AGG 3', reverse 5' GCG TGA GTT CTT TGG AAA GC 3'; osteopontin (783 bp, corresponding to bases 115-897 of the bovine sequence, EMBL accession no. M66236): forward 5' CCA GTT AAA CCG ACC AGT TC 3', reverse $5^{\prime}$ ATT GAC CTC AGA AGA GGC AC 3'; integrin $\alpha_{v}$ (398 bp, corresponding to bases 234-631 of the bovine sequence, EMBL accession no. U10866): forward 5' TGT GAA CCA GAG TCG TCT GC $3^{\prime}$, reverse 5' CAT CCA GAG CAT GGG GAC $3^{\prime}$; integrin $\beta_{1}$ (400 bp, corresponding to bases 1451-1850 of the bovine sequence, EMBL accession no. U10865): forward 5' GTG AAC AGC GAA GAC ATG GA 3', reverse 5' AGA CTC CAA GGC AGG TCT GA 3'; integrin $\beta_{3}(211 \mathrm{bp})$ : forward 5' G(C/T)G $\mathrm{A}(\mathrm{C} / \mathrm{T}) \mathrm{G} \mathrm{A}(\mathrm{A} / \mathrm{G}) \mathrm{A} \mathrm{A}(\mathrm{A} / \mathrm{G}) \mathrm{A} \mathrm{T}(\mathrm{C} / \mathrm{T}) \mathrm{G}$ GCT GG $3^{\prime}$, reverse $5^{\prime}$ TTC TG(T/G) GA(C/T/G) AG(C/T) TTC TC(A/G) GTC AT 3'; and glyceraldehyde-3-phosphate dehydrogenase (GAPDH) (338 bp, corresponding to bases 194-531 of the bovine sequence, EMBL accession no. U85042): forward 5' TCC AGG AGC GAG ATC CTG 3', reverse $5^{\prime}$ ATC CAC AGT CTT CTG GGT GG 3'.

The size of each specific RT-PCR product is assigned in parentheses. Each PCR reaction contained $5 \mu \mathrm{l}$ of the cDNA reaction, $0.2 \mathrm{mmol} d \mathrm{dNTP}^{-1}, 0.4 \mu \mathrm{mol}$ of each primer, 0.5 units Taq DNA polymerase (QIAGEN, Valencia, CA) and a 1:10 dilution of the $10 \times$ concen- trated QIAGEN PCR buffer (supplied with the polymerase) in a final volume of $25 \mu \mathrm{l}$.

The following individual amplification programmes were run in a thermocycler (Personal Cycler, Biometra, Göttingen) for each factor. GAPDH: 28 cycles at $94^{\circ} \mathrm{C}$ $1 \mathrm{~min}, 60^{\circ} \mathrm{C} 1 \mathrm{~min}$; osteopontin (387 bp PCR product): 34 cycles at $94^{\circ} \mathrm{C} 1 \mathrm{~min}, 60^{\circ} \mathrm{C} 1 \mathrm{~min}$; osteopontin (783 bp PCR product): 40 cycles at $94^{\circ} \mathrm{C} 1 \mathrm{~min}, 60^{\circ} \mathrm{C} 1 \mathrm{~min}$; integrin $\alpha_{\mathrm{v}}$ : 34 cycles at $94^{\circ} \mathrm{C} 1 \mathrm{~min}, 60^{\circ} \mathrm{C} 1 \mathrm{~min}$; integrin $\beta_{1}: 27$ cycles at $94^{\circ} \mathrm{C} 1 \mathrm{~min}, 60^{\circ} \mathrm{C} 1 \mathrm{~min}$; integrin $\beta_{3}: 40$ cycles at $94^{\circ} \mathrm{C} 30 \mathrm{sec}, 60^{\circ} \mathrm{C} 1 \mathrm{~min}$.

An 185 rRNA PCR (324 bp) was also carried out for each sample. The $18 \mathrm{~S}$ primers and the appropriate competimers were used in a ratio of 2:3 (Ambion); 24 amplification cycles were performed $\left(94^{\circ} \mathrm{C}, 60^{\circ} \mathrm{C}\right.$ and $72^{\circ} \mathrm{C}, 30 \mathrm{~s}$ each).

All PCR programmes started with an initial denaturation step at $94^{\circ} \mathrm{C}$ for 2 min and ended with an elongation phase at $72^{\circ} \mathrm{C}$ for $2 \mathrm{~min}$.

Five $\mu$ l of each reaction mixture was subjected to electrophoresis on a $1.5 \%$ agarose gel containing $1 \mu \mathrm{g}$ ethidium bromide $\mathrm{ml}^{-1}$ and resultant bands were visualized under UV light. Gels were documented with the Eagle Eye video system (Strategene, La Jolla, CA). All RT-PCR reactions were performed twice for each RNA sample. Preliminary experiments were carried out with increasing numbers of cycles to define number of cycles within the linear range for each primer set to ensure that reactions did not reach a plateau in synthesis. PCR products were cut from the gel and eluted using the QIA quick gel extraction kit (QIAGEN). The purified PCR products were sequenced using their respective forward and reverse primers (Penn State Life Sciences Facility, University Park, PA) to confirm specific amplification of PCR products.

Reactions containing no template (water) or nonreverse transcriptased RNA (negative controls) were included to verify that obtained PCR products were not derived from contaminations or genomic DNA. In all oviductal RNA samples, products were obtained for the corresponding CDNA, but not for genomic DNA under the above described conditions.

\section{Densitometric and statistical analysis}

The molecular mass and the intensity for individual bands on the scanned western blots were determined using Molecular Analyst software (Bio-Rad). Scanned band intensities of the specific RT-PCR products were estimated using Gel-Pro Analyzer software (Media Cybernetics, Silver Spring, MD) after subtraction of background for each lane. Densitometric data were supported by visual impressions of band intensities. All data from RT-PCR were analysed by ANOVA. When ANOVA showed significant differences the Bonferroni test was used to test significance. These calculations were 


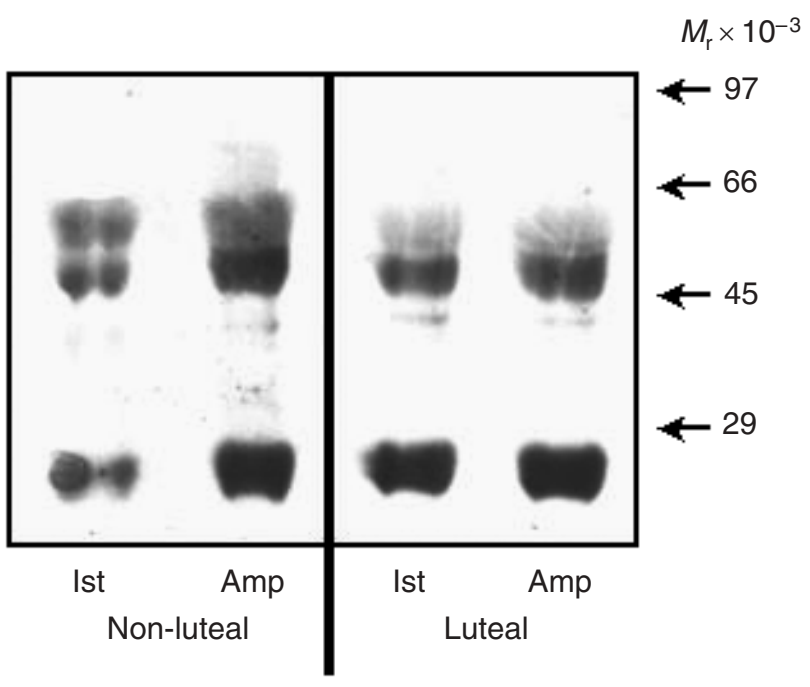

Fig. 1. Western blot analysis of osteopontin in pooled oviductal fluids ( $n=13$ cows for each single pool collected from the isthmus for each oestrous cycle phase and $n=7$ cows for each single pool collected from the ampulla for each oestrous cycle phase). Ist: isthmus; Amp: ampulla; $M_{\mathrm{r}} \times 10^{-3}$ : molecular weight markers.

performed with InStat (Version 3.0, GraphPad Software, San Diego, CA).

\section{Results}

\section{Western blot analysis}

Polyclonal antiserum raised against bovine milk osteopontin recognized predominantly three specific bands at $25 \mathrm{kDa}, 48 \mathrm{kDa}$ and $55 \mathrm{kDa}$ (Fig. 1), in oviductal fluid. These three osteopontin forms were detected in fluid pools from both regions of the oviduct and were present during both the luteal and non-luteal phase. There were also two very weak bands visible at $70 \mathrm{kDa}$ and $42 \mathrm{kDa}$, but not in all pools.

The greatest total osteopontin was detected in oviductal ampullar fluid during the non-luteal phase. Less total osteopontin was observed during the luteal phase in both the isthmic and ampullar fluids but the least total osteopontin was noted during the non-luteal phase in isthmic fluids.

The $25 \mathrm{kDa}$ osteopontin isoform was most prevalent during the luteal phase, accounting for $70 \%$ of the total detected osteopontin. However, this $25 \mathrm{kDa}$ isoform accounted for only $45 \%$ and $62 \%$ of the total osteopontin in the isthmus and ampulla during the non-luteal phase, respectively. Furthermore, the content of the $55 \mathrm{kDa}$ osteopontin form was higher during the non-luteal phase (accounting for $9 \%$ and $35 \%$ of the total osteopontin in the ampulla and in the isthmus, respectively) compared with very weak signals during the luteal phase (accounting for $1 \%$ of the total osteopontin). The highest content of the $48 \mathrm{kDa}$ osteopontin form was observed dur- ing the non-luteal phase in the ampulla, compared with fluids from the other oestrous cycle phases and regions.

\section{Osteopontin and integrin $m R N A$ analysis}

RT-PCR of the house-keeping gene GAPDH and the $18 \mathrm{~S}$ rRNA was performed to monitor the integrity of the RNA as well as the efficiency of the reverse transcription for each sample. The expression of the ribosomal $18 \mathrm{~S}$ RNA was similar among the samples for phases of the oestrous cycle (Fig. 2). Expression of GAPDH showed significant variation during the oestrous cycle. Lowest expression was observed during the late luteal phase compared with other stages (Fig. 2). Therefore, the $18 \mathrm{~S}$ rRNA was used as the internal control for the experiments.

Specific osteopontin transcripts were detected in bovine oviductal cells by RT-PCR (Fig. 3). A primer pair that resulted in different sizes of amplified cDNA (380 bp) and genomic DNA (1100 bp) was used for the first set of experiments. In all oviductal RNA samples, a signal was detected at $380 \mathrm{bp}$ but not at $1100 \mathrm{bp}$ under these amplification conditions. No significant regulated osteopontin expression was observed during the oestrous cycle phases (Figs 2 and 3 ), although expression tended to be higher during the early luteal phase and lower before ovulation.

A PCR was performed with a set of primers for osteopontin designed to result in a product of $783 \mathrm{bp}$ (bases 115-897) spanning over almost the entire coding sequence for the mature peptide (bases 112-897; Kerr et al., 1991) (Fig. 4). Only one specific PCR product was observed at the expected length of $783 \mathrm{bp}$ and no signal for a shorter PCR product was detected. All amplified osteopontin PCR products showed $100 \%$ identity to the known bovine osteopontin gene.

Several integrin mRNA transcripts were also detected in bovine oviductal cells (Figs 2 and 5). In contrast to osteopontin, the integrins showed significant variation in expression during the oestrous cycle. Significantly lower integrin $\alpha_{v}$ mRNA content was observed during the late luteal phase compared with a fourfold higher expression during the early to mid-luteal and the pre-ovulatory phase (Fig. 5a).

The lowest integrin $\beta_{3}$ mRNA content was observed in the oviduct during the late luteal phase and increased significantly to the highest amount before ovulation. Expression tended to be lower during the post-ovulatory and early luteal phases compared with the pre-ovulatory phase (Fig. 5b).

Integrin $\beta_{1}$ also showed the significantly lowest mRNA expression during the late luteal phase compared with its expression near ovulation and the early to mid-luteal phase (Fig. 5c).

Sequencing of the integrin PCR products showed $100 \%$ similarity to the known bovine sequences for integrin $\alpha_{v}$ and integrin $\beta_{1}$. A 211 bp part of the bovine 

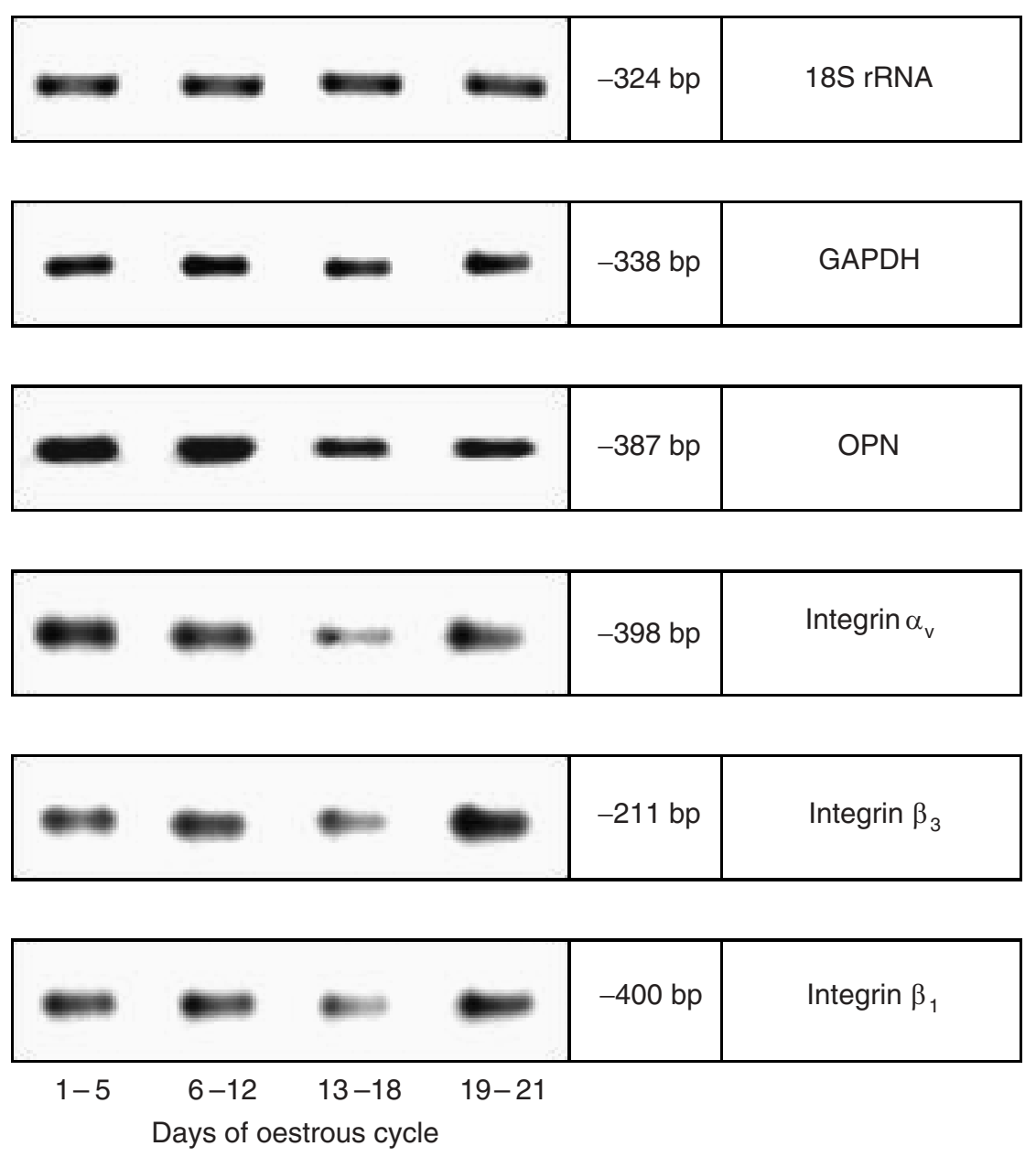

Fig. 2. Specific RT-PCR products for osteopontin (OPN), integrin $\alpha_{v}$, integrin $\beta_{3}$, integrin $\beta_{1}$, glyceraldehyde-3-phosphate dehydrogenase (GAPDH) and 18S rRNA separated by agarose gel electrophoresis. One representative result is shown for each oestrous cycle phase $(n=4)$. Days $1-5$ : post-ovulatory phase; days $6-12$ : early to mid-luteal phase; days 13-18: late luteal phase; days 19-21: pre-ovulatory phase.

sequence was obtained for the integrin $\beta_{3}$ subtype. The bovine integrin $\beta_{3}$ CDNA (EMBL no. AJ297965) was $92 \%$ homologous to the known pig integrin $\beta_{3}$ cDNA (EMBL no. AF282890), 91\% homologous to the human integrin $\beta_{3}$ CDNA (EMBL no. HSU95204) and only $86 \%$ homologous to mouse integrin $\beta_{3}$ gene (EMBL no. AF026509). The deduced amino acid sequence of the bovine integrin $\beta_{3}$ protein showed a high similarity to the human $(100 \%)$ and pig $(98.5 \%)$ protein and $94.2 \%$ similarity to the mouse integrin $\beta_{3}$ protein.

\section{Discussion}

This study established that the oviduct is a source of osteopontin and several integrins. This observation indicates that the osteopontin protein localized by immunohistochemistry in the oviduct epithelium in an earlier study (Gabler et al., 1999) was produced locally within the oviduct. The present findings are in agreement with studies of the human Fallopian tube (Brown et al., 1992) that reported positive staining for osteopontin as a band at the luminal surface and localization of mRNA for osteopontin in oviductal epithelial cells by in situ hybridization. Western blot analysis detected osteopontin protein in fluid from both the ampullar and isthmic regions of the oviduct. Collectively, these findings support the conclusion that osteopontin is synthesized by the oviduct epithelium and is secreted or released from the epithelium into the luminal fluid.

Three osteopontin isoforms of different molecular mass $(55 \mathrm{kDa}, 48 \mathrm{kDa}$ and $25 \mathrm{kDa}$ ) were detected in bovine oviductal fluid. A similar pattern of three osteopontin isoforms of $70 \mathrm{kDa}, 45 \mathrm{kDa}$ and $25 \mathrm{kDa}$ was observed in ovine endometrium extracts (Johnson et al., 1999b). The possible presence of different splicing forms 


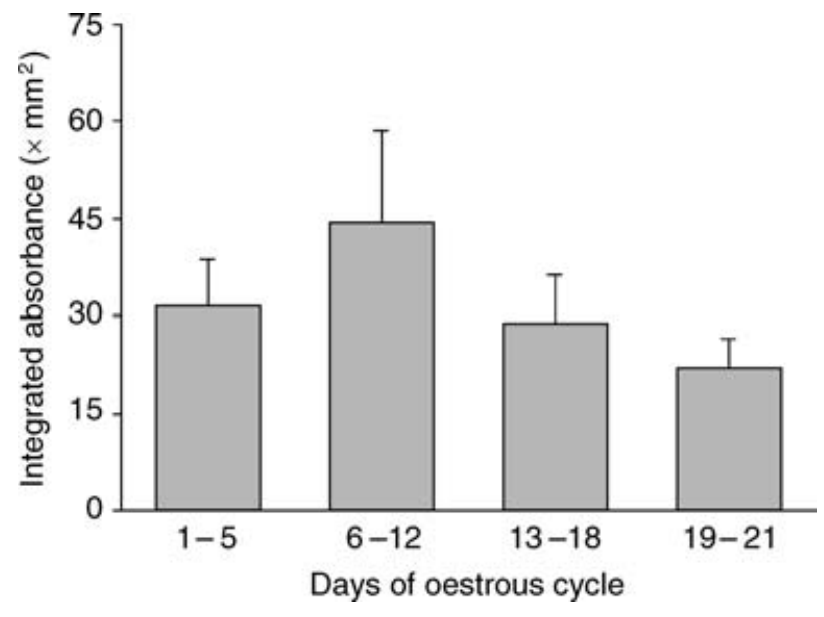

Fig. 3. Densitometric analysis of specific RT-PCR products for osteopontin (387 bp) in bovine oviductal cells (days 1-5: postovulatory phase; days 6-12: early to mid-luteal phase; days 1318: late luteal phase; days 19-21: pre-ovulatory phase). The corresponding integrated absorbance (mean $\pm \mathrm{SEM} ; n=4$ cows for each oestrous cycle phase) is shown. There were no significant differences in osteopontin mRNA content between the oestrous cycle phases.

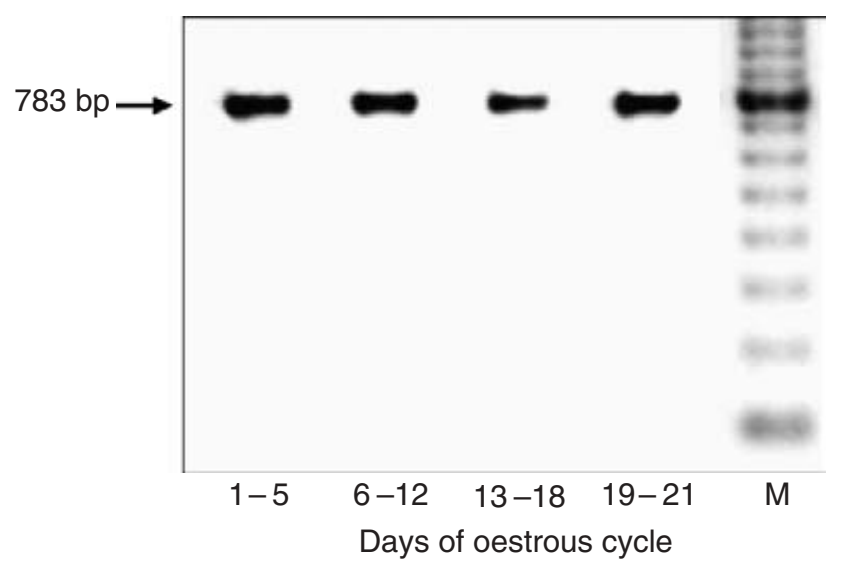

Fig. 4. Specific RT-PCR products spanning almost the entire coding sequence of osteopontin (783 bp) separated by agarose gel electrophoresis. One representative result is shown $(n=4$ cows for each oestrous cycle phase). Days 1-5: post-ovulatory phase; days 6-12: early to mid-luteal phase; days 13-18: late luteal phase; days 19-21: pre-ovulatory phase; M: 100 bp marker.

for osteopontin in the bovine oviduct was accounted for by using primers in the RT-PCR to obtain a product spanning almost the entire coding region for the mature osteopontin protein. However, only one specific band for osteopontin was observed, leading to the conclusion that only one osteopontin transcript was present in the bovine oviduct. This conclusion is consistent with data published from a bovine bone cell cDNA library containing only one osteopontin mRNA transcript (Kerr et al., 1991). The authors postulate that post-translational
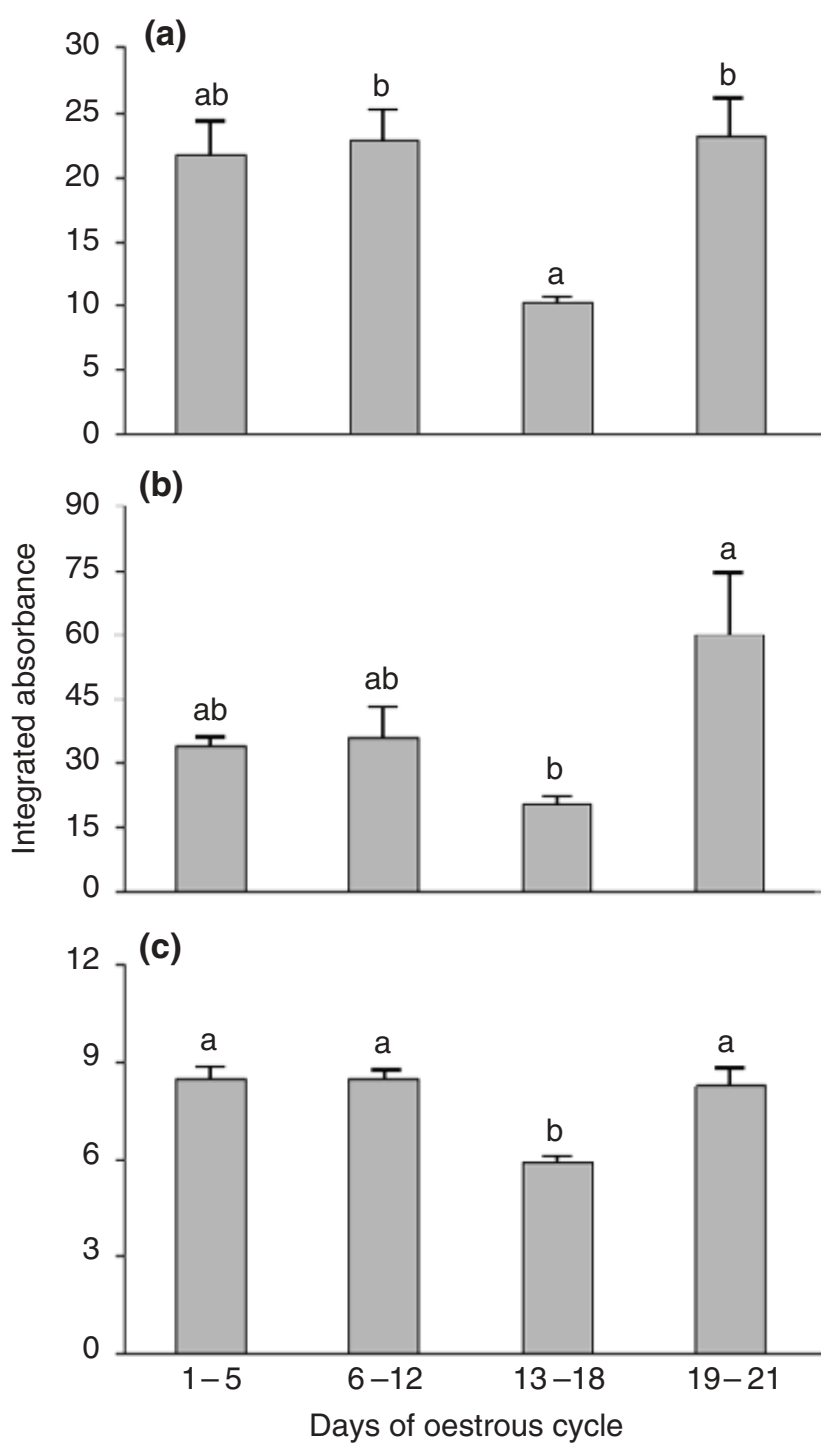

Fig. 5. Densitometric analysis of specific RT-PCR for (a) integrin $\alpha_{v}$, (b) integrin $\beta_{3}$ and (c) integrin $\beta_{1}$ in bovine oviductal cells. Days 1-5: post-ovulatory phase; days $6-12$ : early to mid-luteal phase; days 13-18: late luteal phase; days 19-21: pre-ovulatory phase. The corresponding integrated absorbance (mean \pm SEM; $n=4$ cows for each oestrous cycle phase) is shown. Different letters above the columns indicate significant differences between the columns: a and b; $P<0.05$.

modifications of osteopontin account for the isoforms of different size that were observed. The deduced amino acid sequence of bovine osteopontin predicted a molecular mass of $30946 \mathrm{Da}$ and cell-free transcription produced a $40 \mathrm{kDa}$ protein (Kerr et al., 1991). It is known that bovine osteopontin is a multi-phosphorylated glycoprotein (Sorensen et al., 1995). Bovine milk osteopontin possesses 28 phosphorylation sites and three $\mathrm{O}$-glycosylation sites. In addition, there are three more putative $\mathrm{N}$-glycosylation sites which showed no glycosylation in the bovine mammary gland. Given the 
number of possible sites for modification, it is likely that the $55 \mathrm{kDa}$ and $48 \mathrm{kDa}$ isoforms of osteopontin in the bovine oviduct result from various extents of post-translational phosphorylation or glycosylation. The physiological importance of the different modifications is unknown. The differences in the amount of each isoform detected during the oestrous cycle may be the result of post-translational modifications or cleavage, because the RT-PCR data in the present study revealed only a tendency for higher expression during the luteal phase.

An interesting structural feature of osteopontin is the presence of a thrombin cleavage site close to the RGD region (Denhardt and Guo, 1993) resulting in $23 \mathrm{kDa}$ and $30 \mathrm{kDa}$ cleavage products (Zhang et al., 1990). This may provide greater accessibility of the RGD domain to cell surface receptors after thrombin cleavage. Thrombincleaved osteopontin promoted markedly greater cell attachment and spreading in several cell lines (Senger et al., 1994). Given the molecular weight of the $25 \mathrm{kDa}$ protein detected with the osteopontin antibody in the bovine oviductal fluid, it is possible that this osteopontin form is a product of a thrombin cleavage. However, it is possible that this osteopontin isoform may be generated through a different protease. The detected $25 \mathrm{kDa}$ osteopontin isoform was most prevalent during all phases and regions, indicating that an active osteopontin isoform is present in the oviduct fluid. The relative amount of total osteopontin content for the $25 \mathrm{kDa}$ and $55 \mathrm{kDa}$ isoforms changed during the non-luteal phase compared with the luteal phase. The lower relative amount of $25 \mathrm{kDa}$ osteopontin during the non-luteal phase was accompanied by a relative increase of the $55 \mathrm{kDa}$ form. These changes, occurring at the time of fertilization, may indicate that different osteopontin isoforms play functional roles involving gamete interaction and early embryo development. Another explanation may be that more of the $25 \mathrm{kDa}$ osteopontin isoform in the oviduct fluid was bound to the epithelium near ovulation when there was increased integrin mRNA in oviductal epithelial cells.

Only the $55 \mathrm{kDa}$ isoform was observed in bovine seminal plasma (Cancel et al., 1997), whereas a $70 \mathrm{kDa}$ and a cleaved $45 \mathrm{kDa}$ osteopontin isoform were detected in ovine uterine flushings (Johnson et al., 1999a). This finding indicates that the multiple osteopontin isoforms may play different roles in fertilization, early embryo development and placentation.

The integrin $\alpha_{v} \beta_{3}$ is especially known to bind osteopontin via the RGD region (Rodan, 1995). Antibodies raised against the integrin $\alpha_{v} \beta_{3}$ or only the $\beta_{3}$ chain inhibited osteopontin-mediated effects of cell attachment and cell migration (Liaw et al., 1994; Yue et al., 1994). However, osteopontin can bind to a site other than the RGD region of integrins, as a cleavage product without the RGD binding domain was able to bind to the integrin $\alpha_{v} \beta_{3}$ (van Dijk et al., 1993). In addition, integrin $\alpha_{v} \beta_{1}$ and $\alpha_{v} \beta_{5}$ act as receptors for osteopontin (Hu et al., 1995; Liaw et al., 1995). Smith et al. (1996) showed that only the $\mathrm{N}$-terminal fragment with the RGD region was recognized by the $\alpha_{9} \beta_{1}$ integrin which was unable to bind the native osteopontin. In the present study, the oestrous cycle-dependent expression of integrins in the bovine oviduct was greater for the integrin subunits before ovulation compared with the late luteal phase. This result indicates that more osteopontin could be bound by integrin $\alpha_{v} \beta_{3}$ near ovulation than during the inactive late luteal cycle phase.

It is also possible that other integrin dimers containing the subunits $\alpha_{v}, \beta_{1}$ or $\beta_{3}$ may function in events surrounding fertilization and early embryo development. In the oviduct in humans, several integrin subunits were localized by immunohistochemistry (Sülz et al., 1998). The $\alpha_{v}$ subunit was present in the epithelium during the entire ovulatory cycle, in contrast to integrin $\beta_{3}$ which showed weak staining in the epithelium during the luteal phase, but increased substantially around ovulation. The $\alpha_{1}$ and $\alpha_{4}$ subunits were localized only in the stroma. These results indicate that several integrins are synthesized in the oviduct and some are regulated during the oestrous cycle.

The precise role that osteopontin and integrins play in the oviduct remains to be demonstrated. Integrin $\beta_{1}$ on the outer surface membrane (Glander and Schaller, 1993) and integrin $\beta_{1}$ mRNA (Rohwedder et al., 1996) have been reported in human spermatozoa. Pig oocytes contain integrin subtypes $\alpha_{v}$ and $\beta_{1}$ (Linfor and Berger, 2000). A working hypothesis is that integrins on the spermatozoa and oocyte surfaces may provide sites for attachment between gametes or to the epithelium via osteopontin. A similar binding hypothesis has been proposed for the attachment of the embryo and the endometrium via interaction between osteopontin and integrins (Johnson et al., 1999b).

Osteopontin may also play an immunological role in the oviduct. It is known that osteopontin binds to the CD44 receptor on lymphocytes and monocytes to induce chemotaxis to the site of inflammation (Weber and Cantor, 1996). Osteopontin also binds antigen and suppresses T-helper cells (Fresno et al., 1981).

The results of the present study support the concept that bovine oviductal cells produce osteopontin and several integrins as potential binding sites for osteopontin and vice versa. The authors suggest that this cell attachment system may play an important role in the in vivo oviductal environment for interactions between the gametes, the embryo and the epithelium.

The assistance of the staff at the J. O. Almquist Research Center is greatly appreciated. The authors thank E. Sorensen of the Protein Chemistry Lab, University of Aarhus, Denmark for providing bovine milk osteopontin. This study was supported by USDA (no. 9635203-3428). 


\section{References}

Apparao KB, Murray MJ, Fritz MA, Meyer WR, Chambers AF, Truong PR and Lessey BA (2001) Osteopontin and its receptor alphavbeta(3) integrin are coexpressed in the human endometrium during the menstrual cycle but regulated differentially Journal of Clinical Endocrinology and Metabolism 86 4991-5000

Blobel CP, Wolfsberg TG, Turck CW, Myles DG, Primakoff $P$ and White JM (1992) A potential fusion peptide and an integrin ligand domain in a protein active in sperm-egg fusion Nature 356 248-252

Bradford MM (1976) A rapid and sensitive method for the quantitation of microgram quantities of protein utilizing the principle of protein-dye binding Analytical Biochemistry 72 248-254

Brown LF, Berse B, Van de Walter L, Papadopoulos-Sergiou A, Perruzzi CA, Manseau EJ, Dvorak HF and Senger DR (1992) Expression and distribution of osteopontin in human tissues: widespread association with luminal epithelial surfaces Molecular Biology of the Cell 3 11691180

Cancel AM, Chapman DA and Killian GJ (1997) Osteopontin is the 55kilodalton fertility-associated protein in Holstein bull seminal plasma Biology of Reproduction 57 1293-1301

Cancel AM, Chapman DA and Killian GJ (1999) Osteopontin localization in the Holstein bull reproductive tract Biology of Reproduction $\mathbf{6 0}$ 454-460

Chomczynski P and Sacchi N (1987) Single-step method of RNA isolation by acid guanidinium thiocyanate-phenol-chloroform extraction Analytical Biochemistry 162 156-159

Denhardt DT and Guo X (1993) Osteopontin: a protein with diverse functions FASEB Journal 7 1475-1482

Franzen A and Heinegard D (1985) Isolation and characterization of two sialoproteins present only in bone calcified matrix Biochemical Journal $232715-724$

Fresno M, McVay-Boudreau L, Nabel G and Cantor H (1981) Antigenspecific T lymphocyte clones. II. Purification and biological characterization of an antigen-specific suppressive protein synthesized by cloned T cells Journal of Experimental Medicine 153 1260-1274

Gabler C, Lauer B, Einspanier A, Schams D and Einspanier R (1997) Detection of mRNA and immunoreactive proteins for acidic and basic fibroblast growth factor and expression of the fibroblast growth factor receptors in the bovine oviduct Journal of Reproduction and Fertility 109 213-221

Gabler C, Chapman DA, Gerena RL, Sorensen ES and Killian GJ (1999) Osteopontin is present in the bovine oviduct epithelium and luminal fluid Biology of Reproduction 60 Supplement 1186 (Abstract)

Glander HJ and Schaller J (1993) Beta 1-integrins of spermatozoa: a flow cytophotometric analysis International Journal of Andrology 16 105-111

Helfrich MH, Nesbitt SA, Dorey EL and Horton MA (1992) Rat osteoclasts adhere to a wide range of RGD (Arg-Gly-Asp) peptide-containing proteins, including the bone sialoproteins and fibronectin, via a beta 3 integrin Journal of Bone and Mineral Research 7 335-343

Hu DD, Lin EC, Kovach NL, Hoyer JR and Smith JW (1995) A biochemical characterization of the binding of osteopontin to integrins alpha $v$ beta 1 and alpha v beta 5 Journal of Biological Chemistry 27026 232-26 238

Huang Z, Fasco MJ and Kaminsky LS (1996) Optimization of DNase I removal of contaminating DNA from RNA for use in quantitative RNAPCR Biotechniques 20 1012-1020

Hynes RO (1992) Integrins: versatility, modulation, and signaling in cell adhesion Cell 69 11-25

Ireland JI, Murphee RL and Coulson PB (1980) Accuracy of predicting stages of bovine estrous cycle by gross appearance of the corpus luteum Journal of Dairy Science 63 155-160

Johnson GA, Spencer TE, Burghardt RC and Bazer FW (1999a) Ovine osteopontin: I. Cloning and expression of messenger ribonucleic acid in the uterus during the periimplantation period Biology of Reproduction $61884-891$

Johnson GA, Burghardt RC, Spencer TE, Newton GR, Ott TL and Bazer FW (1999b) Ovine osteopontin II. Osteopontin and $\alpha_{v} \beta_{3}$ integrin expression in the uterus and conceptus during the periimplantation period Biology of Reproduction $\mathbf{6 1} 892-899$
Kavanaugh JF, Grippo AA and Killian GJ (1992) Cannulation of the bovine ampullary and isthmic oviduct Journal of Investigative Surgery 5 11-17

Kerr JM, Fisher LW, Termine JD and Young MF (1991) The cDNA cloning and RNA distribution of bovine osteopontin Gene 108 237-243

Killian GJ, Chapman DA, Kavanaugh JF, Deaver DR and Wiggin HB (1989) Changes in phospholipids, cholesterol and protein content of oviduct fluid of cows during the oestrous cycle Journal of Reproduction and Fertility 86 419-426

Kyhse-Andersen J (1984) Electroblotting of multiple gels: a simple apparatus without buffer tank for rapid transfer of proteins from polyacrylamide to nitrocellulose Journal of Biochemical and Biophysical Methods $\mathbf{1 0}$ 203-209

Lessey BA, Damjanovich L, Coutifaris C, Castelbaum A, Albelda SM and Buck CA (1992) Integrin adhesion molecules in the human endometrium. Correlation with the normal and abnormal menstrual cycle Journal of Clinical Investigation 90 188-195

Lessey BA, Castelbaum AJ, Buck CA, Lei Y, Yowell CW and Sun J (1994) Further characterization of endometrial integrins during the menstrual cycle and in pregnancy Fertility and Sterility 62 497-506

Liaw L, Almeida M, Hart CE, Schwartz SM and Giachelli CM (1994 Osteopontin promotes vascular cell adhesion and spreading and is chemotactic for smooth muscle cells in vitro. Circulation Research $\mathbf{7 4}$ 214-224

Liaw L, Skinner MP, Raines EW, Ross R, Cheresh DA, Schwartz SM and Giachelli CM (1995) The adhesive and migratory effects of osteopontin are mediated via distinct cell surface integrins. Role of alpha $v$ beta 3 in smooth muscle cell migration to osteopontin in vitro. Journal of Clinical Investigation 95 713-724

Linfor J and Berger T (2000) Potential role of alphav and beta1 integrins as oocyte adhesion molecules during fertilization in pigs Journal of Reproduction and Fertility 120 65-72

Miyauchi A, Alvarez J, Greenfield EM et al. (1991) Recognition of osteopontin and related peptides by an $\alpha_{v} \beta_{3}$ integrin stimulates immediate cell signals in osteoclasts Journal of Biological Chemistry $26620369-20374$

Nomura S, Wills AJ, Edwards DR, Heath JK and Hogan BL (1988) Developmental expression of 2ar (osteopontin) and SPARC (osteonectin) RNA as revealed by in situ hybridization Journal of Cell Biology 106 $441-450$

Oldberg A, Franzen A and Heinegard D (1986) Cloning and sequence analysis of rat bone sialoprotein (osteopontin) cDNA reveals an Arg-GlyAsp cell-binding sequence Proceedings National Academy of Sciences USA 83 8819-8823

Prince CW (1989) Secondary structure predictions for rat osteopontin Connective Tissue Research 21 15-20

Rodan GA (1995) Osteopontin overview Annals of the New York Academy of Sciences 760 1-5

Rodriguez CM, Day JR and Killian GJ (2000) Osteopontin gene expression in the Holstein bull reproductive tract Journal of Andrology 21 414-420

Rohwedder A, Liedigk O, Schaller J, Glander HJ and Werchau H (1996) Detection of mRNA transcripts of $\beta_{1}$ integrins in ejaculated human spermatozoa by nested reverse transcription-polymerase chain reaction Molecular Human Reproduction 2 499-505

Ross FP, Chappel J, Alvarez II, Sander D, Butler WT, Farach-Carson MC, Mintz KA, Robey PG, Teitelbaum SL and Cheresh DA (1993) Interactions between the bone matrix proteins osteopontin and bone sialoprotein and the osteoclast integrin alpha $v$ beta 3 potentiate bone resorption Journal of Biological Chemistry 268 9901-9907

Schaller J, Glander HJ and Dethloff J (1993) Evidence of beta 1 integrins and fibronectin on spermatogenic cells in human testis Human Reproduction 8 1873-1878

Senger DR, Perruzzi CA, Papadopoulos-Sergiou A and Van de Water L (1994) Adhesive properties of osteopontin: regulation by a naturally occurring thrombin cleavage in close proximity to the GRGDS cellbinding domain Molecular Biology of the Cell 5 565-574

Siiteri JE, Ensrud KM, Moore A and Hamilton DW (1995) Identification of osteopontin (OPN) mRNA and protein in the rat testis and epididymis, and on sperm Molecular Reproduction and Development 40 16-28 
Smith LL, Cheung HK, Ling LE, Chen J, Sheppard D, Pytela R and Giachelli CM (1996) Osteopontin N-terminal domain contains a cryptic adhesive sequence recognized by alpha9beta1 integrin Journal of Biological Chemistry 27128 485-28 491

Sorensen ES, Hojrup P and Petersen TE (1995) Post-translational modifications of bovine osteopontin: identification of twenty-eight phosphorylation and three O-glycosylation sites Protein Science 4 2040-2049

Sülz L, Valenzuela JP, Salvatierra AM, Ortiz ME and Croxatto HB (1998) The expression of $\alpha_{v}$ and $\beta_{3}$ integrin subunits in the normal human Fallopian tube epithelium suggests the occurrence of a tubal implantation window Human Reproduction 13 2916-2920

van Dijk S, D'Errico JA, Somerman MJ, Farach-Carson MC and Butler WT (1993) Evidence that a non-RGD domain in rat osteopontin is involved in cell attachment Journal of Bone and Mineral Research 8 14991506

von Wolff M, Strowitzki T, Becker V, Zepf C, Tabibzadeh S and Thaler CJ (2001) Endometrial osteopontin, a ligand of beta3-integrin, is maximally expressed around the time of the 'implantation window' Fertility and Sterility 76 775-781
Weber GF and Cantor H (1996) The immunology of Eta-1/osteopontin Cytokine \& Growth Factor Reviews 7 241-248

Yue TL, McKenna PJ, Ohlstein EH, Farach-Carson MC, Butler WT, Johanson K, McDevitt P, Feuerstein GZ and Stadel JM (1994) Osteopontinstimulated vascular smooth muscle cell migration is mediated by beta 3 integrin Experimental Cell Research 214 459-464

Zhang Q, Domenicucci C, Goldberg HA, Wrana JL and Sodek J (1990) Characterization of fetal porcine bone sialoproteins, secreted phosphoprotein I (SPPI, osteopontin), bone sialoprotein, and a 23-kDa glycoprotein. Demonstration that the $23-\mathrm{kDa}$ glycoprotein is derived from the carboxyl terminus of SPPI Journal of Biological Chemistry 265 7583-7589

Received 18 June 2003.

First decision 5 August 2003.

Revised manuscript received 29 August 2003.

Accepted 29 August 2003. 